MA MAJOR RESEARCH PAPER

\title{
THEME AND STRUCTURE: KEY ELEMENTS IN THE CRITERIA FOR EXCELLENCE IN JOURNALISM
}

Anna Dorbyk

The Major Research Paper is submitted in partial fulfillment of the requirements for the degree of Master of Arts

Joint Graduate Program in Communication \& Culture

Ryerson University - York University

Toronto, Ontario, Canada

March 4, 2007 


\section{TABLE OF CONTENTS}

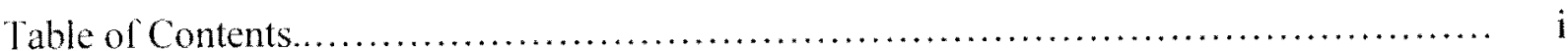

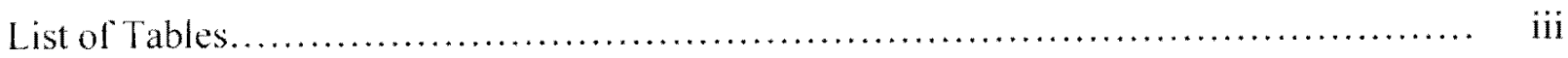

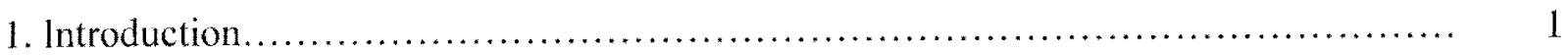

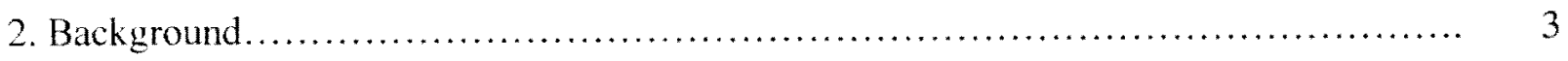

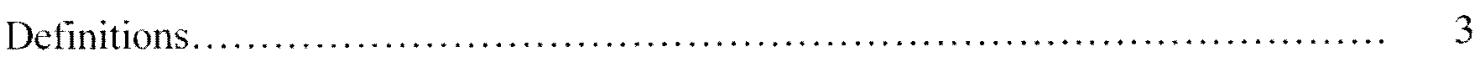

1. Distinctions Between Principles and Standards in Journalism.................... 3

2. Indicators of Newspaper Quality........................................ 5

3. Distinguishing Between Quality and Excellence.............................. 8

The Emergence of Theme................................................................................ 9

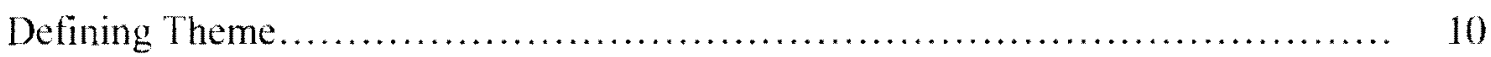

Conventional Journalistic Writing and Organizational Strategies..................... 12

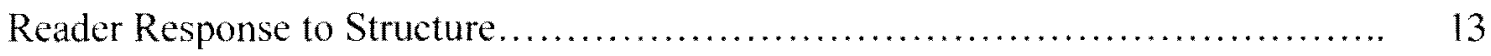

The Need to Identify Specific Characteristics of Content.......................... 14

3. Data Corpus................................................................. 15

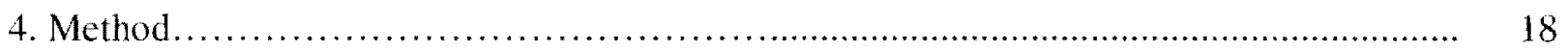

5. Results and Discussion.............................................. 22

The Importance of Theme in Awards...................................... 25

Themes Absent from the Awards............................................. 26 
Comparison with a Similar Study ....................................... 27

The Link Between Newspaper Resources and Awards......................... 27

Geographic Distribution of Awards...................................... 29

Case Study: The Globe and Mail........................................ 30

The Regional Deficit in Awards....................................... 31

The Structures of Award-Winning Articles....................... 33

The Shift in Structure and Style Reflected in Award Recognition............ 36

The Word Count Factor............................................. 38

The Gender Factor...................................................... 39

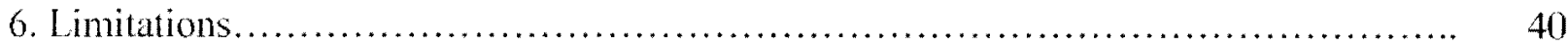

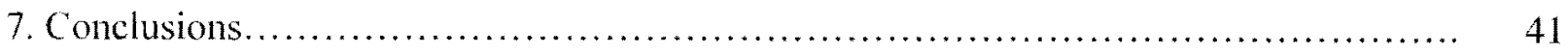

The Significance of Theme............................................. 42

Relevance of Article Structure to Excellence................................ 43

Factors Common to Award-Winning Articles............................. 44

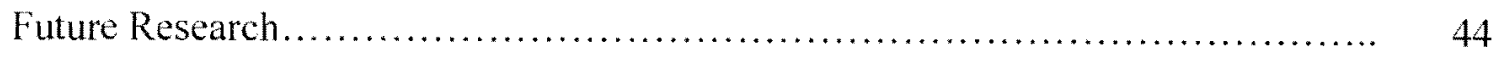

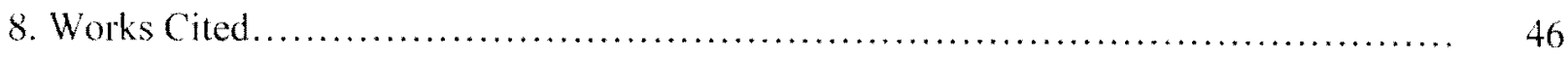




\section{LIST OF TABLES AND FIGURES}

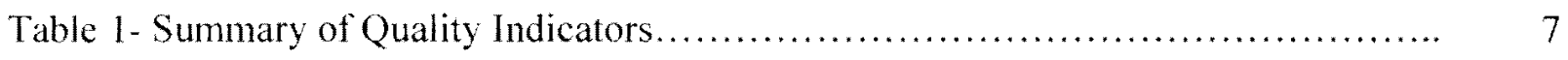

Table 2- A List of 30 Recurring Newspaper Article Themes.......................... 11

Figure 3- Illustration of Co-Occurring Concepts Map $\ldots \ldots \ldots \ldots \ldots \ldots \ldots \ldots \ldots \ldots \ldots \ldots . \ldots \ldots$

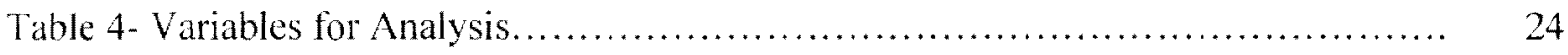

Table 5-The Most Frequently Recurring Newspaper Story Themes.................. 26

Figure 6- Distribution by Percentage of Host Newspapers for Sampled

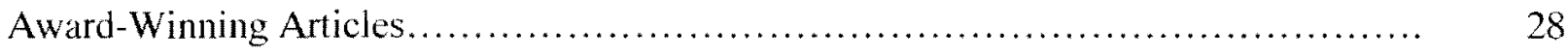

Table 7- Globe and Mail: Geographic Focus of Award-winning Articles............. 31

Table 8- All Award-Winning Newspapers: Geographic Focus Factors

Influencing the likelihood of success......................................... 32

Table 9- Story Structure by Theme of Award-winning Articles, .................... 35

Table 10- Number of Award-winning Articles in Each of Five Word Count Ranges..... 38

Table 11-Gender Distribution of Award-winning Writers .......................... 39 


\section{INTRODUCTION}

Journalism it is often claimed, is a social instrument that is the chief means by which citizens become informed and equipped to be active participants in democratic life. As Kovach expresses this point "the role of the press since its beginning has been to help the people overcome the scarcity of information upon which they could make thoughtful and informed decisions" (Kovach http:/www,concernedjournalists.org/node/492). The higher the standard of journalism, therefore, the more effectively it can fulfill its role. However, questions arise of precisely what is meant by standards of excellence in journalism and furthermore, what are the criteria by which it can be measured? As an area of research, criteria for journalistic excellence remain difficult to define and challenging to measure and quantify. Since industry awards programs devoted to recognizing the best in journalism would reasonably be expected to stipulate their understanding of excellence, they would appear a logical place to begin the task of investigating what constitutes journalistic excellence. Shapiro et al., however, have reported that "many [awards] programs simply don't have judging guidelines, while others consist mostly of lists of terms, without explanation or illustration" (7).

Without evidence of excellence criteria being available from those industry programs and institutions whose professional role it is to recognize excellence, scholars have had to broach the subject in different ways. Some studies devoted to the goal of naming concrete characteristics of excellence have sought to define "excellence" by interviewing judges, journalists and newspaper editors. These have resulted in individually subjective answers. Other research initiatives have measured journalistic writing by equating quality with conformity to traditional journalistic 
standards such as "accuracy" and "impartiality" (Bogart 45). Like the subjective opinion of industry professionals, any list of standards in journalism is potentially elusive because of the manifold variables that influence conclusive final judgment. For some industry professionals though, these references to the more enduring standards of the profession "would be seen... not as criteria of excellence... but as bare minimum requirements" (Shapiro et al. 6). Shapiro et al. advanced the understanding of "excellence" by reinforcing the presence of these traditional journalistic standards, and by demonstrating that the weighting each judge placed on these criteria was subject to individual preference. While the weighting of criteria of excellence may be subjective, this study's findings indicate that there are indeed commonalties among awardwinning articles, and these relate to two main variables: theme and structure.

The New Dictionary of Cultural Literacy defines theme as "a central idea in a piece of writing or other work of art" (459). In journalism, the theme of the article conveys the specific message intended by the author. Similarly, the structure of the article as consciously utilized by the journalist organizes the content and helps to support the central theme of the piece. Shapiro et al"s claim that "writing is likely to carry the most weight at the end of the judging process... (20)“ must now be further analyzed in concert with the theme of the writing.

Accordingly, in an effort to better understand journalistic excellence, this study analyzed the content of award-winning Canadian journalism from the year"s 2000 to 2006 through the dual lenses of theme and structure. 
From this approach to award-winning newspaper articles a typology of content characteristics was created. These characteristics include both thematic emphasis and writing style as they are deployed to highlight the themes in award-winning articles. Some preliminary findings presented here highlight frequently occurring themes, writing structures and other patterns in Canadian award-winning journalism.

\section{BACKGROUND}

Quality and excellence are not synonymous terms in the evaluation of journalistic writing. While a work may exhibit the traditional ethical and professional journalistic standards judged to be measures of quality, they are not sufficient in themselves in determining excellence. They are nevertheless prerequisites of excellence, and so achieving an understanding of what may constitute criteria for excellence requires first a close consideration of what the general standards of quality in journalism might be and how these standards could be achieved.

\section{Definitions}

\section{Distinctions Between Principles and Standards in Journalism}

Outside of journalistic textbooks that seek to teach would-be reporters how to craft a piece that measures up to the principles and standards of the industry, a number of scholars have also attempted to define these measures. Kovach and Rosensteil state that "Over the last three hundred years, news professionals have developed a largely unwritten code of principles and values to fulfill the function of providing news- the indirect knowledge by which people come to form their opinions about the world" (38). Accordingly, Kovach and Rosensteil declare that "truthfulness" is the foremost principle because, "since news is the material that most people use 
to learn and think about the world beyond themselves, the most important quality is that it be usable and reliable"(ibid). Kovach and Rosensteil do not address the subjective nature of the concept of "truth" however. Usefulness and reliability, governed by the principle of "truthfulness" emerge, then, as the core values underpinning journalistic standards according to Kovach and Rosensteil. Following from this in what is tantamount to a requisite code of journalistic conduct, Kovach and Rosensteil offer nine statements of operational goals: an unwavering "obligation...to the truth," an utmost loyalty to citizens, a respect for journalism as a "discipline of verification." a commitment to maintain "an independence from those they cover," a focus on serving as "an independent monitor of power," the ability to "provide a forum for public criticism and compromise," a desire to "strive to make the significant interesting and relevant," to keep the news "comprehensive and proportional," and the freedom to "exercise their personal conscience" (Kovach and Rosensteil 12-13).

Other scholars have outlined similar, if not identical principles and standards for the journalism industry (Tsalati, Meyers and Perri, 2006; Strentz, 2002). So too have a number of journalistic organizations comprising editors, writers and other industry personnel committed to the advancement of the trade. The American Society of Newspaper Editors and The Poynter Insitute both outline on their websites sets of core values and principles in journalism that mirror Kovach and Rosensteil"s nine statements of operational goals. As an addition to this list, however, both contribute new principles including a commitment to "reflecting and serving diverse readers" (The American Socicty of Newspaper Editors, 2007) and "accessibility" (Poynter Institute, 2007) for all citizens. As Kovach and Rosensteil among others (Gardner, Csikszentmihalyi and Damon, 
2001 ; Shapiro, Albanese and Doyle, 2005) point out, these factors in principle are generally agreed upon in the journalistic community, but "do not masquerade as agreed standards of excellence,"....still [they] "have started a widespread discussion on these standards..." (Shapiro, Albanese and Doyle 5). This discussion has led to a number of scholars attempting to clarify indicators of journalistic quality.

\section{Indicators of Newspaper Quality}

A consideration of the enduring principles and standards in newspaper journalism serves to clarify some of the operational goals of the industry. These goals reinforce many of the aspirational values in journalism as they apply to the industry and to each individual journalist. They do not, however, necessarily demarcate any standards related to the overall quality of the publication. In addition to this work on the principles and standards the journalistic community should subscribe to, there is also scholarly work that points to creating quality indicators as distinct from the principles and standards in journalism. A number of scholars have attempted to isolate indicators of journalistic quality. Merrill, 1968; Ghiglione, 1973; Bogart, 1977; Meyer and Kim, 2003 have pointed out such factors as "ease of use, localism, editorial vigor, news quantity and interpretation" (Meyer and Kim 1). Statistically elusive abstractions and a vulnerability to subjectivity, however, are still evident in such measures as "editorial vigor".

In another effort, John Merril used his research data to outline a "five point guideline... of newspaper quality indicators" including "independence, strong opinion and interpretive emphasis, emphasis on politics, international relations, economics, social welfare, cultural 
endeavours, education and science" (Merril 2). But again, the criticisms against Merril's research stated that his guidelines for quality were too subjective and difficult to measure. Some years later, Merril in conjunction with Lowenstein attempted to revise his criteria for newspaper quality, making his guidelines more objective and more readily implemented. These guidelines developed from an internal assessment of the newspaper included "good typography and makeup techniques, editing and proofreading care, correct spelling, punctuation and grammar, picture reproduclion and printing excellence, balance in editorial/news material, concern with staff quality, concern with editorial policy and concern with self-evaluation and outside criticism"(Merril and Lowenstein 1973).

Like Merril and Lowenstein, George Gladney also isolated "internal" criteria for evaluating newspaper quality, which he termed "organization standards", noting such criteria as "integrity, staff enterprise, community leadership, editorial independence, staff professionalism, editorial courage, decency, influence, and impartiality"(Gladney 1996). Gladney also isolated nine content standards including news interpretation, lack of sensationalism, strong local appeal, visual appeal, accuracy, strong editorial page, CP standard, comprehensive coverage and good writing. In total, Gladney abstracted from the literature 18 journalistic quality standards which he then used to survey newspaper editors, asking them to rank the importance of each standard. This technique of abstracting standards and surveying judges, newspaper personnel or readers is a technique echoed in some of Gladney"s earlier work in conjunction with others (Gladney, Shapiro and Castaldo 2005). His results showed that most editors and readers were in agreement on the organizational and content standards deemed most important including "integrity" and 
"lack of sensationalism" (Gladney 1996). Gladney"s efforts to identify characteristics of editorial quality based on the opinions of editors and readers made a useful contribution to the study of quality in journalism. However, in the process, Gladney uses the terms "standards" and "excellence" interchangeably and thereby fails to distinguish between terms which designate distinctly different characteristics as noted by Shaprio, Albanese and Doyle 2005.

Table 1: Summary of Quality Indicators

\begin{tabular}{|c|c|c|c|c|c|c|c|c|c|c|c|c|c|c|c|c|c|c|c|c|c|c|}
\hline & 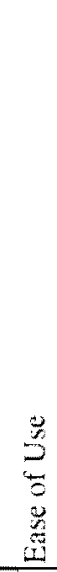 & & 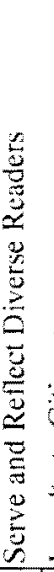 & 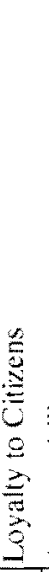 & & & & & 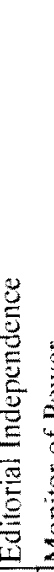 & 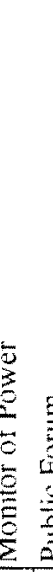 & & 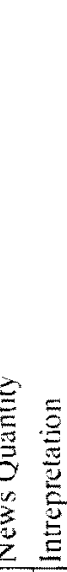 & 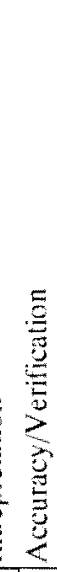 & 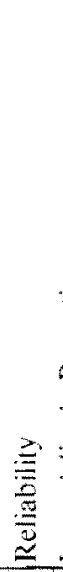 & 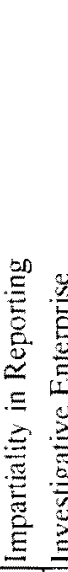 & 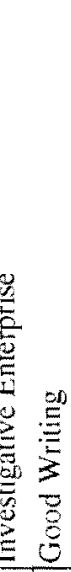 & 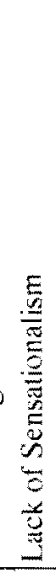 & 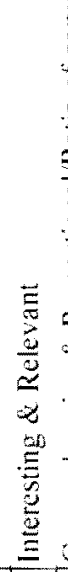 & 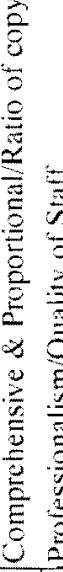 & & & 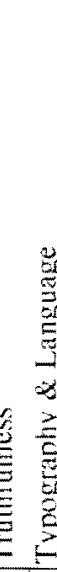 \\
\hline Bongart & & & & $\mathrm{x}$ & & & & $\mathrm{x}$ & & & & $x$ & $x$ & & \begin{tabular}{l|l}
$x$ & 1 \\
\end{tabular} & \begin{tabular}{l|l}
$x$ & $x$ \\
\end{tabular} & & 1 & $x \mid$ & & & \\
\hline Kovach \& Rosensicil & & & & $x$ & & & & $\mathrm{X}$ & $x$ & $x:$ & $x$ & & $x$ & $\mathrm{x}$ & $x$ & & & $x$ & $\mathrm{x}$ & & & $\mathrm{x}$ \\
\hline Gladney & & & & $\mathrm{x}$ & $\mathrm{x}$ & $\mathrm{x}$ & $\mathrm{x}$ & $\mathrm{x}$ & $x L$ & & & $\mathrm{X}$ & $\mathrm{x}$ & & $x[y$ & \begin{tabular}{l|l}
$x$ & $x$ \\
\end{tabular} & $x$ & & 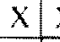 & & & $x: 7$ \\
\hline Meyer \& Kim & $x$ & & & 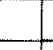 & & & $\mathrm{x}$ & $\mathrm{X}$ & & & & $x \mid x$ & & & 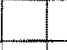 & & 5 & 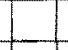 & $T$ & & & \\
\hline Merril & & & & & & & & & $\mathrm{x}$ & & & $x$ & & & & & & & $\mathrm{x}$ & & & \\
\hline Merril \& Lowenstein & & & & & $x$ & & & & $\mathrm{x}$ & & & & & & & & & & $x$ & & & 3 \\
\hline The American Socicly of Newspaper Editors & & & $\mathrm{x}$ & $\mathrm{x}$ & & & & $x$ & $x[$ & $\mathrm{x}$ & $\mathrm{X}$ & & $\mathrm{x}$ & $\mathrm{x}$ & $\mathrm{x}$ & & & $\mathrm{x}$ & $x_{L}$ & & & $x$ \\
\hline Poynter Institule & & $x$ & $\mathrm{x}$ & $\mathrm{x}$ & & & & $\mathrm{x}$ & $\mathrm{x}$ & $x$ & $x$ & & $x$ & $\mathrm{x}$ & $x$ & & & $x$ & $x$ & & & $x$ \\
\hline Tstatlit. Meyers \& Perri & & & $\mathrm{x}$ & & & & & $\mathrm{X}$ & & & & $x$ & $6 x$ & & $x$ & & $\mathrm{x}$ & $x$ & & & & \\
\hline Strenty. & & & & & $\mathrm{x}$ & & & & & $\mathrm{X}$ & & & & $\mathrm{x}$ & & & & & & & & X \\
\hline
\end{tabular}

These standards adduced by each of the studies concerned with isolating criteria for quality state factors that are historically associated with ethical and professional quality standards in journalism, but they do not stipulate what might constitute excellence in journalism. Further, these indicators of quality pertain either to the overall organizational goals of the publication or 
to its editorial objectives. This is to say, none of these quality standards pertain to individual journalistic works, but instead address the over-arching goals of the industry and the range of print publications in it.

\section{Distinguishing between Quality and Excellence}

While the terms "quality" and "excellence" are used interchangeably, as demonstrated in the work of Gladney (1996) and Bogart (2004), they are not synonymous; they identify different aspects of journalistic writing. However, they are related since "quality" is said to be an essential feature of "excellence." Still, Shapiro et al. attempt to differentiate "excellence" from quality by proposing criteria for excellence in journalism in their 2005 investigation of Canada's two leading national print journalism awards programs.

Utilizing the technique of directly surveying judges of awards competitions, Shapiro et al. illuminated the process by which judges assign awards by conducting a survey of selected judges, and asking them to weigh the importance of a list of predetermined criteria of journalistic excellence extracted from the results of a thorough survey of awards guidelines and other literature on the subject. As Shapiro et al. noted, "not only had journalism awards judges never been surveyed about their criteria, but the literature failed to provide a clear starting point for a list of standards that could be readily applied to individual works of journalism"(11). 
Findings taken from their research did indicate that writing style, reporting rigour, and amount and depth of reporting are frequently recurring criteria for excellence as cited by awards judges, although these categories somewhat beg the question as they offer limited reference to quantifiable measures. Not surprisingly, given the largely non-scientific nature of the awards process, the researchers further discovered that the judges surveyed felt compelled to make judgments guided by the standards of the journalistic community, but in the final analysis often relied on their own subjective opinion.

In their 2005 study, Shapiro et al. made a significant and necessary contribution to the research area of criteria for excellence in journalism. Their study exposed the subjective, non-scientific character and the potential arbitrariness of award selection. In their study of those criteria that affect the determination of excellence as indicated by judges of journalism awards, Shapiro et al. asked: "How important... is the subject matter of a story in determining its excellence" (4)? This study made crucial first steps; however, in order to know more precisely what is meant by excellence in journalism, it is necessary to shift from an analysis of the overall newspaper and awards process and instead identify the more specific characteristics found in the content of award-winning print articles: an analysis of theme is one way to do this.

\section{The Emergence of Theme}

In their analysis of an American sample Lamb and Moore attempted just such an enterprise. Based on a content analysis of 31 Pulitzer Prize-winning feature articles spanning the 25 years of the category"s existence, Lamb and Moore attempted to isolate recurring thematic patterns. Their 
findings revealed a number of factors amenable to coding and quantifying, including the discovery that a significant proportion of these feature articles had a local slant and were concerned with themes that might evoke negative or sad emotions. Lamb and Moore's study and its findings on the recurrence of themes in Pulitzer Prize winning feature articles should be considered as only preliminary. The current study builds on Lamb and Moore's findings by expanding the analysis to a cross-category consideration of three national awards, and also considering the role that writing structure plays in concert with theme.

\section{Defining Theme}

A consideration of the thematic properties of award-winning journalistic articles should not be undertaken without first being clear on the definition of "theme." Lamb and Moore do not specifically define the term, but do utilize another study in their research that attempts to do so. In its media project the Readership Institute of the Media Management Center at Northwestern University used 74,000 articles taken from daily newspapers to compile a list of 26 recurring themes in daily newspapers. According to the study, theme refers to "What's the story about?" (Readership Institute, 4). Here we must distinguish between the subject matter which is the specific event that makes the news and theme which is why the event is newsworthy. So, a toxic spill, as a subject, is newsworthy because of the urgency of the theme environment. It is the thematic emphasis that gives a journalist the opportunity to differentiate their story from others focused on the same subject. Further, theme specifies content type and in the classification of different themes the reader must be careful not to confuse the story's content with the newspaper section in which it appears. Bogart (1977) also deconstructed the typical American newspaper 
into 44 sections. While many of these sections such as Automotive or Food represent the general organizational categorization provided by newspaper's (also referred to as Beats), some of the sections specifically indicate theme. Four of Bogart's sections including Public Health/Welfare. Social Problems/Protest, Labour/Wages and Energy Problems are more theme-specific and therefore for the purposes of this study could be incorporated into the list of themes for the present study"s analysis. The combination of 26 themes identified by the Readership Institute and the four themes identified by Bogart, were combined to create a list of 30 themes used in the present study.

Table 2: A List of 30 Recurring Newspaper Article Themes

\begin{tabular}{|c|c|c|c|c|}
\hline 1.Politics/Government & $\begin{array}{l}\text { 2.Police/Crime/Couris/ } \\
\text { Legal }\end{array}$ & $\begin{array}{l}\text { 3. Nalural } \\
\text { Disaster/Accident }\end{array}$ & $\begin{array}{l}\text { 4. Business/ } \\
\text { Economics/ } \\
\text { Personal } \\
\text { Finance }\end{array}$ & 5. Sports \\
\hline $\begin{array}{l}\text { 6. War/International } \\
\text { Conllict }\end{array}$ & $\begin{array}{l}\text { 7. Parenting } \\
\text { Relationships }\end{array}$ & $\begin{array}{l}\text { 8. Sciencel } \\
\text { Technology }\end{array}$ & $\begin{array}{l}\text { 9. Health/ } \\
\text { Filness/ } \\
\text { Medicine }\end{array}$ & 10. Education \\
\hline 11. Jobs/Carcer & 12. Aulomolive & 13. Travel & 14.Environment & $\begin{array}{l}\text { 15. Religion/ } \\
\text { Spirituality }\end{array}$ \\
\hline 16. Ordinary Pcople & $\begin{array}{l}\text { 17. Home/Garden/Real } \\
\text { Estate }\end{array}$ & 18. Food & 19. Movies & 20. Popular Music \\
\hline 21. Television & 22. The Arts & $\begin{array}{l}\text { 23.Communily } \\
\text { Announcements }\end{array}$ & 24. Obituaries & $\begin{array}{l}\text { 25. Fashion/ } \\
\text { Beauty }\end{array}$ \\
\hline 26. Other & $\begin{array}{l}\text { 27. Public } \\
\text { Heallh/Wellare }\end{array}$ & $\begin{array}{l}\text { 28. Social } \\
\text { Problems/Prolest }\end{array}$ & $\begin{array}{l}\text { 29. Labour/ } \\
\text { Wages }\end{array}$ & $\begin{array}{l}\text { 30. Encrgy } \\
\text { Problems }\end{array}$ \\
\hline
\end{tabular}

A consideration of what themes may be seen to reoccur over time as present in award-winning print journalism leads into new territory. A study of recurring thematic patterns is one way of quantifying content characteristics in award-winning stories. This would represent a definite advancement in the search for concrete criteria for excellence in journalism. To begin with, an exploration of recurring themes in award-winning articles may shed light on actual criteria 
deployed by judges when assessing for excellence in journalism. Furthermore, it may become possible to speculate on what themes judges recognize as excellent. Beyond appeal and frequency more concrete and subtle characteristics can also be noted.

\section{Conventional Journalistic Writing and Organizational Structures}

The structure and organization of a news article is one of the essential rudiments of the journalistic practice. Although different techniques for formulating a story will have been taught, the structure and organization of a news article is one of the essential rudiments of the practice: "Although readers may not be consciously aware of a story's structure, they will be more likely to read a story that has a clear structure" (Kershner 59). For this reason, it is not unreasonable to suggest that the judges of awards competitions would also respond to news articles that are well structured and in recognizable accord with conventional journalistic organizational strategies. "Whether it is a long feature story or a short news brief, a news story should have a pattern of development" (ibid).

Journalistic textbooks teach would-be writers the specifics of such patterns including the three structural patterns isolated in the present study, namely, inverted pyramid, hourglass and feature writing style.

- Inverted pyramid: The inverted pyramid is the classic structure for many news stories and in fact. "most breaking news stories are written in [the style] in which the most important of the five W`s and $\mathrm{H}$ are in the lead" (Itule and Anderson 61). According to Itule and 
Anderson, "the inverted pyramid structure places facts in descending order of importance. The rest of the story in the inverted pyramid structure simply adds supporting facts and details in descending order of importance"(ibid).

- Hourglass Structure: The hourglass strueture "begins, like an inverted pyramid, with a summary lead explaining the whole story. Then the writers include a chronology of events in order and finally return to a general summary at the end of the story"(ibid). Yet, not all news events will be suited to either aforementioned structure.

- Feature Style Structure: "If a story lends itself to feature-writing techniques, it probably will have a clear beginning, middle and end"(Itule and Anderson 63). Narrative writing characterized by vivid descriptions and the author's personal interpretation will also be utilized to create a flow that follows through to the story's conclusion. The feature writing style will also often incorporate a feature lead that does not present facts necessarily, but rather attempts to "hook" the reader with a compelling question or descriptive beginning to the story. A feature story will likely also utilize dialogue, quotations, a strong voice, and effective transitional devices (ibid).

\section{Reader Response to Struclure}

Utilizing these conventional journalistic devices for organization and presentation is never arbitrary. Each time a journalist writes an article he or she makes a conscious decision about how their story will be best received by their audience based on the known editorial standards of the 
publication. The organization and presentation of a news story is so crucial to its reception that a number of scholars have conducted research into what audience"s respond to when reading (Hendrickson and Tankard, 1990; Franklin, 1996; Beasley, 1998). Beasley in his study concluded that readers did not favourably respond to a story's structure that used the inverted pyramid style, and made a call for utilizing narrative writing techniques. Hendrickson and Tankard fundamentally agreed with Beasley and discovered that "sentences that show are usually perceived by readers as more interesting, engaging and information rich than sentences that merely tell'(Hendrickson and Tankard 35). Franklin, the first winner of a Pulitzer Prize for feature writing, would likely have disputed both studies. His contrary feeling was that only certain stories were well-suited to a narrative approach, although he did recognize that the use of narrative "could humanize and provide interesting, in-depth explanations... (Lamb and Moore 3)." for a range of subjects that readers might not otherwise understand.

\section{The Need to Identify Specific Characteristics of Content}

In spite of these studies examining judging criteria and theme and structure in isolation, little work has been done to explore characteristics of theme and structure present in award-winning journalism in parallel. Further, these content characteristics including both thematic emphasis and writing style as they are deployed to highlight articles' themes in award-winning articles have not yet been linked to criteria for excellence. In an effort to advance the study of criteria for excellence in journalism, the current study attempts to provide a content-based typology of these characteristics. 
The following research questions guided this study:

- RQ\#1: What recurring themes are present in award-winning Canadian journalism?

- RQ \#2: How is the theme structurally presented or represented?

\section{DATA CORPUS}

Data for this study were taken from and accessed through the Bestjournalism.ca website, a Ryerson School of Journalism initiative that attempts to "further the study and pursuit of excellence in Canadian journalism" (http:/www.firefly.ryerson.ca/journalism/topstories/aboutUs.cfm). The website contains a "continually updated database of award-winning articles that have been singled out as exemplary in national awards programs, in scholarly settings, or by acknowledged leaders in the practice of joumalism“" (ibid). The site houses text articles that have won awards in English language writing categories in national award programs between the years of $2000-2006$. To date, the website houses approximately 225 award-winning newspaper articles and 168 award-winning magazine features. Although the website is in its pilot stages, the site already houses a significant number of newspaper articles that have won national awards in a variety of categories and that focus on a range of thematic categories. The present study used a content analysis to conduct research on winning newspaper articles from three national Canadian awards:

1. The Canadian National Newspaper Awards [NNA] seeks to recognize excellent articles in the following 20 categories: "Breaking News; Investigations; Presentation; Sports; Business; Politics; Long Feature Writing; Short Feature Writing; Columns; Editorial Writing; Arts and 
Entertainment; Special Project; International Reporting; Explanatory Journalism; and Local Reporting (for newspapers under 30.000 circulation)" (http:/www.cnaacj.ca/client/cna/cna.nsf/web/NNAAdmin).

The purpose of the 20 NNA award categories is to provide an organizational template for submissions. Without any evidence to the contrary, there is no reason to believe that these categories predispose the selection of one's subject over another. These categories likely only serve to situate a judge within a particular category. For each of the 20 award categories, the Canadian NNA website does provide limited additional information on criteria for entry, but more comprehensive "guidelines" for assessment to the judges. For example, the entrant guidelines in the "Investigation" category stipulate: "Preference will be given to original, compelling and significant reporting demonstrating successful achievement against difficult circumstances" (http://www.cnj acj.ca/client/cna/cna.nsf/web/NNARules).

The judging guidelines are noticeably more detailed than the criteria listed for entrants, but still are vulnerable to subjective interpretation. The judging guidelines do, however, reflect a number of the traditional standards of quality attributed to the journalistic trade. For example, the judges are directed to look for:

- Idea: Significance (Was it worth reporter and reader spending time on?);

Newsworthiness; Timeliness; Originality and creativity; Humorous; Initiative. 
- Reporting: Depth and breadth; Context and background; Accuracy

Fairness and balance; Comprehensive, relevant sources (officials and real people); Detail that engages reader; Answers readers questions; Enterprise and effort.

- Writing: Language (precision of usage, elegance); Style, tone, mood (appropriate to content); Credibility/authority; Compelling lead/opening; Clarity; Strong focus/theme what is this story about?; Structure and organization; Effective anecdotes quotes and examples; Narrative and description; Accuracy and fairness; Creativity/Risk-taking; Reader interest (ibid).

2. The Canadian Association of Journalists [CAJ] undertakes to serve the profession by promoting "excellence in journalism, [and] encouraging investigative journalism" (http:/www.caj.ca/index.html). The CAJ, it asserts " has three award categories for newspaper reporters: Open Newspaper/Wire service for a newspaper with a circulation greater than 25,000, Community Newspaper for a newspaper with a circulation under 25,000 and Best investigative reporting \& CAJ computer-assisted reporting” (ibid). Unlike the Canadian National Newspaper Awards, the CAJ does not stipulate any useful judging guidelines that might provide evidence of what the organization looks for when recognizing excellence.

3. The Michener Awards are presented annually to "the news organization whose entry is judged to have made a significant impact on public policy or on the lives of Canadians" (htlp://www.michenerawards.ca/english/entryrules.htm). Past winners have been chosen on the basis of hard-hitting reporting, journalistic professionalism and the resources available for the 
project (ibid). The Michener awards site does not stipulate any criteria for the judging of newspaper articles beyond seeking out work dedicated to impacting public policy or the daily lives of Canadians.

\section{METHOD}

This exploratory study endeavours to identify characteristics of excellence in journalism by investigating the specific content of award-winning Canadian articles. To do so, a content analysis of the data corpus was undertaken. Content analysis is a useful method for identifying notable or potentially meaningful content properties in large bodies of text. The unit of analysis in this study was the entire article or single series comprising two or more articles and its constituent individual lexical items.

To assist with a content analysis it was helpful to apply a data management tool, Leximancer: -This is particularly useful for those not familiar with the text and is similar to the grounded theory approach, in which the important themes in the text are meant to appear from the text alone. independent of the observer" (http://www.leximancer.com/documents/hfes2002.pdf). To quickly gain insight into the content of the data set, Leximancer can be configured to map the document for co-oceurrences between concepts. Leximancer defines concepts as "collections of terms that provide evidence for the use of the concept in the text" (ibid). These collections of terms each have a relevancy value that weights how important each term is to its concept. When an article is first run through Leximancer, a thesaurus of terms for each concept is generated. This initial lexical analysis is an iterative process in which the clusters of terms that define a 
concept are updated in each iteration and revised by a process that eliminates some concepts and highlights others. Quite simply, this iterative process highlights how often concepts co-occur with other concepts, and the process halts when saturation is reached and "the number of sentence blocks classified by each concept remains stable" (http:/metacortex.humanfactors.uq.edu.au/lex/Leximancer/Terminology.htm). In other words, the tool provides an exhaustive analytical summary.

From this learning phase, Leximancer extracts the major issues or concepts within a text and represents them graphically and in tabular form. The concepts based on term frequency are presented in a ranked order to illustrate the most frequently occurring individual words in the 1ext. As these co-occurrences identify the main concepts in the text they serve as a data dictionary that provide evidence of how the thematic category eventually assigned to each awardwinning article was chosen. Figure 3 illustrates this graphic concept identification method used to discern theme. 
Figure 3: IIIustration of Co-Occurring Concepts

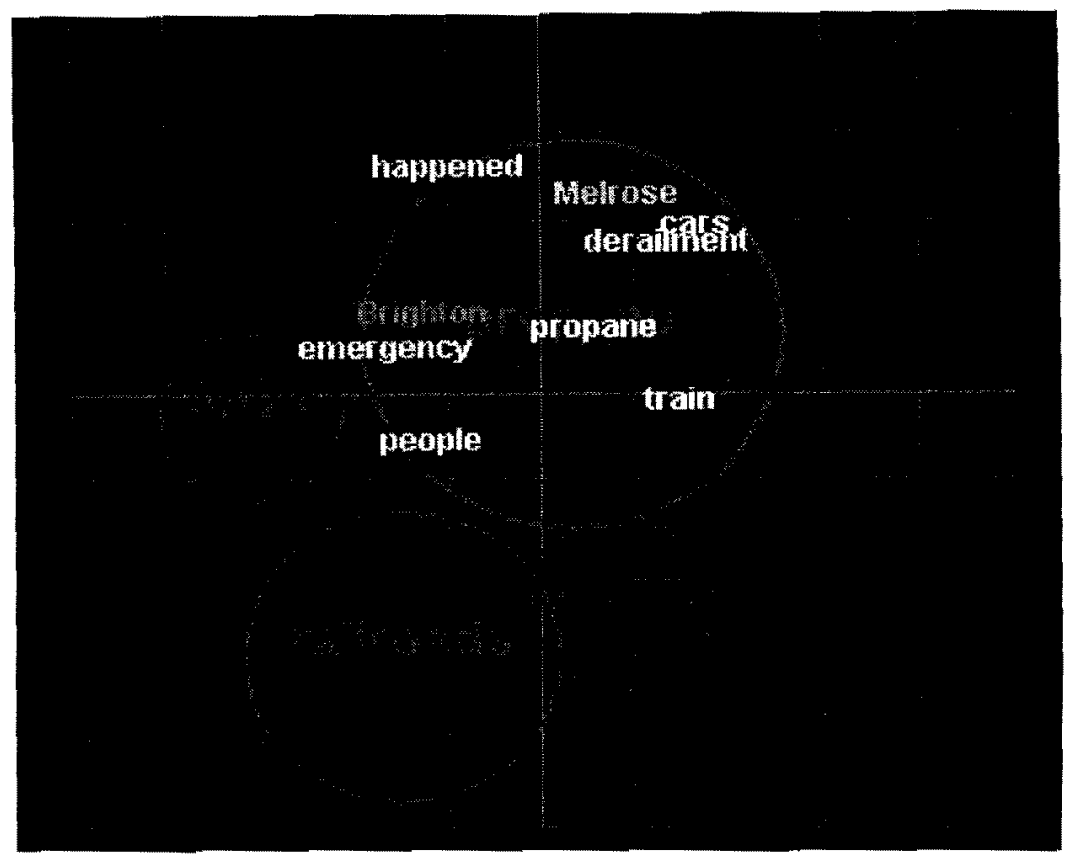

In the article "The Time Bomb That Missed Brighton by Minutes" the map demonstrates that "propane" was the central concept of the piece and the concepts of "town," "railroads," "freight," "year" and "hotbox" are linked by relative proximity and size to this central concept. The concept of "propane" is also surrounded by clusters of frequently co-occurring concepts such as "emergency." "propane," "train" and "derailment." These clusters of concepts indicate the theme accident/natural disaster.

Before beginning this project, the researcher acknowledged that in doing a content analysis there would inevitably be problems in deciding on the theme to which each article would be assigned. Specifically, the researcher anticipated that each of the articles under consideration in this project could potentially have multiple themes and therefore it would be necessary to isolate the dominant thematic emphasis. The possibility of the researcher`s bias was obviated by the 
hicrarchic and co-relational arrangement of frequently occurring concepts displayed by

Leximancer. This means Leximancer was able to identify the most important concepts in the text, especially in relation to each other and thus "provid[ed] the ability to contextualise the meaning" (http:/www.leximancer.com/cms/index.php?option $=$ com_content\&task=view $\& \mathrm{id}=46 \& !$ temid $=$ 87.

In the case of a potential conflict between themes in the article, the researcher assessed the relevance of context in confirming which theme was the more dominant by reading the article. For example, politics/government might appear thematically in conflict with war/international conflict. In discerning the dominant theme, the researcher allowed the context of the article expressed in the title "U.S. Will Never be the Same" to clarify the denotation of the lexical items isolated by Leximancer: "terrorists. Americans, yesterday, few, nation, world, fanatics, revenge." Following these steps in conjunction with a close reading of the article, the researcher determined that the dominant emphasis of the piece was on the violence inflicted against the United States and the war that occurred in consequence. It was evident to the researcher therefore that although concerned with the United States as a subject, the article used words such as "terrorists, Americans and revenge" which identify the article"s predominant theme as war.

The frequency of concept occurrences and the assessment of context, then, helped the researcher to distinguish between principle and sub-ordinate themes. Furthermore, the researcher was guided by the inherited lypology of 30 potential newspaper themes assembled through both the work of the Readership Institute and Bogart. In adhering to this list of possible themes, the 
present study did not encounter any unanticipated newspaper themes. Still, in two instances, the rescarcher did encounter articles whose themes were ambiguous and therefore not readily captured by the typology

In the article, "Absolutely Alive, Absolutely Real into Africa," the author presented a number of perspectives on Africa, a subject that in its depiction by journalists often draws from a set of single themes such as social problems, crime or war. The author of the piece intentionally chose to avoid these familiar themes and instead deployed a number of perspectives which were presented as journalistic opinion. Similarly, in the article, "Suicide Attempt Provokes the Most Difficult of Questions," the author wrote an editorial piece that presented multiple sides of an issue. In both cases, the theme of other was assigned for the simple reason that by intention both of the articles gave equally weighted attention to several sides of their respective stories and thus, neither article highlighted a dominant theme.

For each article in the sample the process followed was designed to gather evidence of the primary theme of the piece. The first step in this process involved running the data mining tool Leximaneer to identify the most frequently recurring concept clusters as displayed in graphical form and list the top ten ranked concepts. These concepts were then recorded by the researcher on a coding sheet under the coding categories "top ten ranked concepts" and "major concepts." On this same coding sheet the researcher also recorded information taken from each awardwinning article's citation on the Bestjournalism.ca website. This information included the article"s title, the series titles (when applicable), the award category in which the article won, and 
the award received. Before assigning the article to one of the 30 potential themes looked for in this sample, the researcher then read the article to confirm the theme. As a final step then, the researcher chose a theme from the typology of 30 themes compiled from the previous work done by the Readership Institute (2001) and Bogart (1989).

The present study used a content analysis to conduct research on winning newspaper articles from three national Canadian awards found on the Bestjournalism.ca website. These Canadian awards were: National Newspaper Awards, Canadian Association of Journalists and the Michener Award. The sample size of this study was dictated by the number of award-winning articles available on the Bestjournalism.ca site in the three chosen national award categories. If the full text of an article was not available on the site and could not be located using the Ryerson University library database, it was excluded from the study. In addition, if an article was mislabeled and actually belonged to the 'magazine' category, it was also omitted from the Sample. After taking into account the above factors, each award contributed the following number of articles: National Newspaper Awards: 122; Canadian Association of Journalists: 28; Michener: 17. Of the articles assembled in this 167 -article data corpus, 19 won an award as a series. It is important to keep in mind though that single series articles appear not to be given less attention in the judging process than a multi-article series, because quantity is not a stated evaluative criterion for any of the three awards sampled. Award-winning articles then, including those in a series were analyzed as one. Condensing articles in a series to one unit therefore, 
resulted in a still smaller sample size of 77 items. To explore whether recurring themes are present in Canadian award-winning journalism each article was examined for the following variables:

Table 4: Variables for Analysis

\begin{tabular}{|l|l|}
\hline Name of Newspaper & Name of Author \\
Title of article & Gender \\
Series Titles (where applicable) & Award Received \\
Circulation Size & Theme \\
Word Count (where documented) & Top Ten Ranked Concepts \\
& Story Structure \\
\hline
\end{tabular}

Gender: For the coding of gender, the name of the author including their publicly available biographies, gender pronouns used in their description and other anecdotal evidence was used to discern the author"s gender. 
Theme: The initial unaided audit of the texts and including the article"s title and/or series title revealed the top ten ranked concepts for each article. These were recorded as evidence of theme.

Story Structure: coded according to ltule and Anderson (2003) in their textbook News Writing and Reporting.

\section{RESULTS AND DISCUSSION}

This study of award-winning Canadian journalism was initiated with the objective of identifying patterns of recurrent story themes and further examining how each theme was structurally organized in line with common journalistic writing and reporting strategies. Mining the data corpus for a range of variables including theme and geographic focus helped to isolate concrete features of award-winning journalism that provide evidence for what arbiters of excellence deem noteworthy and correlate findings with thematic patterns. The foundation for this study was the evidence of recurring themes found in award-winning articles and it is this research consideration that should be assessed first.

\section{The Importance of Theme in Awards}

The findings summarized in Table 5 reveal that a limited number of themes arise from the sample of 77 articles taken from three national awards. Of the 30 potential themes proposed by the Readership lnstitute and Bogart, 16 were not present in the 77 -article sample. 
Table 5: The Most Frequently Occurring Newspaper Story Themes

\begin{tabular}{|c|c|c|}
\hline Theme & $\begin{array}{c}\text { \# of sample arlicles } \\
\text { with theme }\end{array}$ & Percentage of total sample \\
\hline Politics/Governmen! & 13 & $17 \%$ \\
\hline Police/Crime/Courts/Legal & 10 & $13 \%$ \\
\hline Social Problems/Protest & 9 & $12 \%$ \\
\hline Business/Economics/Personal Finance & 8 & $10 \%$ \\
\hline Heallh/Finess/Medicine & 7 & $9 \%$ \\
\hline The Arts & 6 & $7 \%$ \\
\hline Natural Disaster/Accident & 6 & $7 \%$ \\
\hline Sports & 5 & $6 \%$ \\
\hline War/nternational Conllic: & 5 & $6 \%$ \\
\hline Enviromment & 2 & $3 \%$ \\
\hline Other & 2 & $3 \%$ \\
\hline Public Healih/Welfare & 2 & $3 \%$ \\
\hline Religion/Spirituality & 1 & $2 \%$ \\
\hline Ordinary Pcople & 1 & $2 \%$ \\
\hline
\end{tabular}

An analysis of the data summarized in Table 5 reveals that a total of 14 principal story themes occurred in onc or more articles. No single theme emerges as preeminent, and no theme garners a large percent of the total. The top three themes taken together constitute only $42 \%$, and the remaining 11 themes comprise $58 \%$ of the total.

\section{Themes Absent from the Awards}

Of the 16 themes proposed in Table 2 that did not receive awards, several are of a specialized nature and therefore, it would be expected, not likely candidates for recognition. These include automotive, education and travel-themed stories. Of the total 16 excluded themes under discussion, three are highly topical: science and technology, labour and wages, and cnergy problems. Not surprisingly, therefore, their seemingly initial exclusion from the present study 
was uncxpected. The emphasis of these particular themes, however, was not absent in the awardwinning articles, but instead played a secondary role to other dominant themes such as health, litncss and medicine, social problems/protest and natural disaster/accident.

\section{A Comparison with a Similar Study}

It is interesting to compare this study's findings to Lamb and Moore's content-based research into recurring themes in Pulitzer Prize-winning articles, the Pulitzer being perhaps the most prestigious industry prize in American journalism. From a sample of 31 feature stories Lamb and Moore found that the themes of "ordinary people, crime, health, accident or disaster, technology and politics" (5) were the most frequently recurring feature themes. While there is no reason to anticipate precise or exact congruence of themes between the two studies, the commonness of themes confirms the finding that there are a limited number of award-winning themes both in the American and Canadian sample.

\section{The Link Between Newspaper Resources and Awards}

In researching the question of excellence it is to be expected that economic business factors such as circulation size and geographic base are likely to engender journalistic excellence. Before this study was embarked upon, three national awards granted by professional organizations were chosen to provide the professional points of reference at a national level. These awards invite applicants from all newspapers across the country, regardless of the circulation size or resources available to the competitors. That said, with even a cursory review of the findings 
displayed in Figure 6, the actual pattern of geographic distribution among host newspapers of award-winning articles reveals the unmistakable dominance of the large centres of population and political power.

Figure 6: Distribution by Percentage of Host Newspapers for Sampled Award-Winning Articles

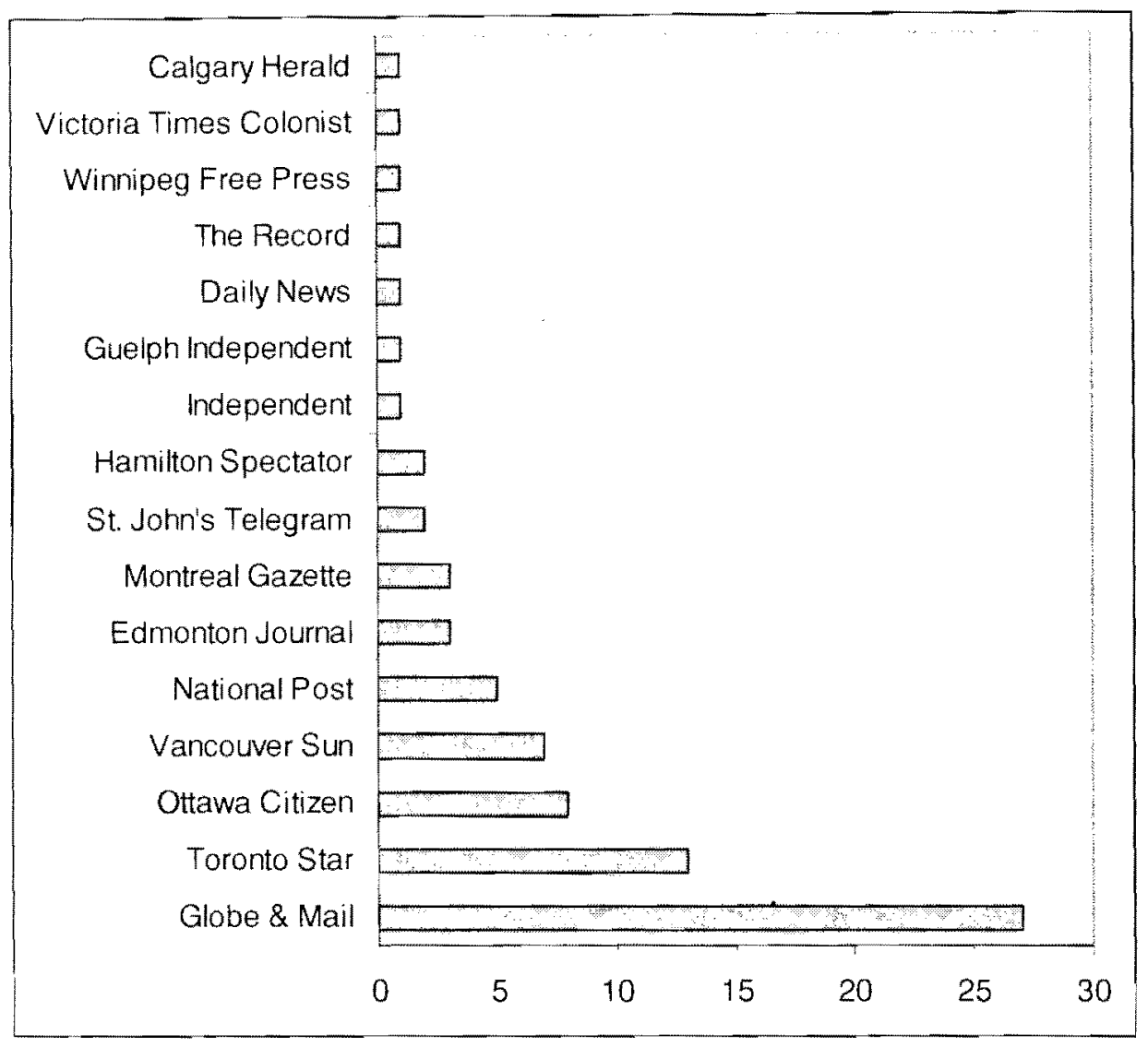

Sixleen newspapers across the country received awards for excellence from the three national professional associations in the sample. The findings of this study indicate that of the top five newspapers from which award-winning articles were submitted, four were from the province of 
Ontario. Further, these top five newspapers accounted for a striking $78 \%$ of all Canadian newspaper sources of award-winning articles in the total sample analyzed. This is put in clear perspective when set in the context of eleven other newspapers that were identified as hosting an award-winning article, but which only accounted for $22 \%$ of all Canadian newspaper sources of award-winning articles.

\section{Geographic Distribution of Awards}

As might be expected, a greater number of newspapers from large cily centers would host the majority of the award-winning articles. Accordingly, research findings indicate that only four newspapers with a circulation size less than 25,000 had an award-winning article originate from their pages. Even so, it was surprising to note how disproportionate the distribution of awardwinning articles to newspapers was. From the sixteen newspapers identified as being the host of at least one of these award-winning journalistic pieces, The Globe and Mail was acknowledged as having the greatest number of award winners. Indeed, the self-proclaimed "national newspaper." although only in Anglophone Canada accounted for over one third of all artieles in the sample with $35 \%$.

This disproportionate number of awards garnered by a single newspaper in competition with fifteen others is reminiscent of concerns voiced elsewhere. Lamb and Moore document opposition to competitive disadvantage inherent in prestigious awards such as the Pulitzer Prize when the competition makes no allowance for applicants who are less well-favoured in market size. audience characteristics or access to resources: the critics have charged that "the largest. 
most prestigious papers take the majority of the prizes" (Lamb and Moore 2). "In other words." as Lamb and Moore conclude from the response to this accusation by a Pulitzer board member, "the better newspapers are superior because they hire top-notch writers; of course, the best writers naturally want to work at the best papers, so the cycle feeds on itself, keeping the same newspapers on top“ (ibid). Undoubtedly, there is much truth in this justification, for the evidence here makes clear that larger circulation national newspapers win high numbers of journalistic awards. With greater resources and an extended reach, a newspaper, such as The Globe and Mail would have an immediate advantage in creating a nationally-known and respected journalistic institution. Still, this conclusion would seem overly simplistic and at worst, unsupported and warranting further attention to the specifics of award-winning articles.

\section{Case Sudy: The Globe and Mail}

It would be expected that the largest newspaper in Canada and one with a wide geographic circulation would focus a large percentage of the total editorial content of the paper on issues pertaining to Canada. Further, being a cosmopolitan newspaper, the Globe and Mail would likely also direct considerable resources to international issues and events. This assumption is supported by the research findings illustrated in Table 7 which indicate that of the 27 awardwinning articles originating from the Globe and Mail, ten of the stories were international in scope. 
Table 7: Globe and Mail: Geographic Focus of Award-winning Articles

\begin{tabular}{|l|c|}
\hline \multicolumn{1}{|c|}{ Geographic Focus } & \# of Articles \\
\hline International & 10 \\
\hline National & 9 \\
\hline Locial & 7 \\
\hline Regional & 1 \\
\hline Total & $\mathbf{2 7}$ \\
\hline
\end{tabular}

This is not surprising "given Canada"s role in the international community, the reporting of international events should be of considerable interest to its citizens" (Soderlund 121). Articles with a national focus closely followed these international-themed stories with nine entries followed by local-themed articles with seven award winners. Articles that had a more specifically regional focus were not well-represented by the Globe and Mail, with only one winning article in this category coming from the newspaper.

\section{The Regional Deficit in Awards}

This lack of winning regional articles was a consistent factor in the total sample. The findings specific to the Globe and Mail illustrated the lack of a regional emphasis in award-winning articles originating from the paper. When the total sample was looked at, a similar finding was again obscrved. As Table 8 clearly demonstrates, articles with a regional emphasis did not appear to receive significant attention in the total sample. Apart from this similarity, the overall demographic focus did change, however, when the total sample was looked at. 
Table 8: All Award-Winning Newspapers: Geographic Focus Factors Influencing the likelihood of success

\begin{tabular}{|l|c|}
\hline \multicolumn{1}{|c|}{ Geographic Focus } & \# of Articles \\
\hline Local & 32 \\
\hline International & 22 \\
\hline National & 18 \\
\hline Regional & 5 \\
\hline Total & 77 \\
\hline
\end{tabular}

Table 8 illustrates that when all 77 award-winning articles and series were analyzed, stories with a local focus were most dominant, accounting for $42 \%$ of the overall sample. In this fuller contexi, international stories made up a significantly smaller $30 \%$ of the sample while national stories totaled $23 \%$. Looked at as a percentage of the total sample, articles with a regional emplasis comprise less than one percent.

The evident regional deficit in this sample is not surprising given the list of newspapers in which the award-winning articles originated. Of the 16 newspapers from which one or more awardwinning articles came, two are considered national, four local and the remaining ten newspapers were from both mid to large-sized Canadian city centres. Accepting that 14 newspapers in the sample have a more local focus, this lack of regionally-themed articles can be expected given that relative to newspapers with a commitment to a national focus "smaller papers are most 
interested in local news stories" (Soderlund 120). Indeed, the majority of newspapers represented in this study either came from small population centres or from larger cities and in both cases, locally-based stories would be expected to dominate the articles of each newspaper.

The data reveal the dominance of winning newspapers from large centres of population in Canada. Specifically, award-winning articles in this sample, more frequently originated from newspapers with a circulation size greater than 25,000. Further, the data also reveal a correlation between the geographic area that the dominant theme described in the article and the newspaper from which the recognized piece originated. The present study suggests that two factors can influence the particular geographic focus described by the award-winning article"s theme: the size of the population centre in which the paper circulates, and the size and scope of the reading audience that forms the paper's market. Further, accounting for the existence of these identified recurring themes in the data corpus is made possible by analyzing the relationship between the theme and the structure of the article. It is this relationship that more deeply reveals the particular subtleties of Canadian awarl-wining articles and illustrates the more quantifiable aspects of excellence as it relates to theme.

\section{The Story Structures of Award-Winning Articles}

This study has been concerned with discovering recurring themes in award-winning Canadian journalism. Thus far, it has been suggested that theme plays an important role in award-winning articles. However, as also noted, an article's theme and its structural framework have an important relationship. Thus, to complete the picture it is necessary to look also at the journalistic 
craft of "writing and reporting." Put simply, this element is the "how" of journalistic writing. Within the "how" reside different structural methods for organizing a journalistic piece. This study set out to discover which of the three widely used structural methods for writing, inverted pyramid, hourglass and feature style, is dominant among the 77 articles analyzed. As Table 9 illustrates the traditional inverted pyramid story structure, which developed with the introduction of the telegraph and was used to structure the early wire stories, is not used as frequently in award-winning articles. The feature writing style was the most common story structure used by authors in each of the articles in the sample. The feature style was utilized in a total of 45 articles, which is almost twice the usage of the hourglass style. As this study was concerned with not only recurring themes in award-winning articles, but also with the story structure of these winning journalistic pieces, it is useful to correlate the use of the three predominant story structures to theme. 
Table 9: Story Structure by Theme of Award-winning Articles

\begin{tabular}{|l|c|c|c|c|}
\hline Theme & $\begin{array}{l}\text { \# of Sample } \\
\text { Articles } \\
\text { with Theme }\end{array}$ & $\begin{array}{l}\text { Inverted } \\
\text { Pyramid }\end{array}$ & Hourglass & Feature \\
\hline Politics/Government & 13 & 4 & 5 & 4 \\
\hline Police/Crime/Courts/Legal & 10 & 3 & 4 & 3 \\
\hline Social Problems/Protest & 9 & & 2 & 7 \\
\hline $\begin{array}{l}\text { Business/Economics/Personal } \\
\text { Finance }\end{array}$ & 8 & & 2 & 6 \\
\hline Health/Fitness/Medicine & 7 & 1 & 2 & 4 \\
\hline The Arts & 6 & & & 6 \\
\hline Natural Disaster/Accident & 6 & & 4 & 2 \\
\hline Sports & 5 & & 3 & 5 \\
\hline War/International Conflict & 5 & & 1 & 1 \\
\hline Environment & 2 & & 1 & 1 \\
\hline Other & 2 & & & 2 \\
\hline Public Health/Welfare & 2 & & & 1 \\
\hline Religion/Spirituality & 1 & & $\mathbf{2 4}$ & 1 \\
\hline Ordinary People & 1 & & $\mathbf{4 5}$ \\
\hline Tolal & $\mathbf{7 7}$ & $\mathbf{8}$ & & 2 \\
\hline
\end{tabular}

The findings illustrated in Table 9 reveal that the feature style of writing, characterized by narrative writing techniques was utilized in articles with story themes most commonly associated with "hard" or information-based news including social problems/protest, business/economics/personal finance and the most frequently recurring award-winning theme, politics/government.

The hourglass style can be seen as a hybrid form of both the inverted pyramid and the feature writing style. The hourglass writing style embraces the importance of story timelines, but also utilizes narrative techniques. This style of journalistic writing also occurred frequently in stories with themes associated with "hard" news such as crime/courts/legal and politics/government. 
them personally, interested them. entertained them and was quick and easy to read"( 20$)$. Even when a news story is concerned with relaying the details of a tragic accident or an escalating international crisis, scholars like Beasley believe that the story achieves greater resonance with a readership when humanized by including for example, language appealing to the senses, quotes, dialogue, all characteristics of the feature writing style.

What is notable about the present study"s findings is that the use of a feature style of writing is not limited to what would be considered the traditional "soft" news stories. In fact, the use of a feature style of writing was noted in articles with a natural disaster/accident, public health/welfare and medicine/health-themed emphasis. Based on these findings, the present study would support the notion that "human interest stories molded by the techniques of fiction, put a face on the bewildering universe of medical ethics, risky procedures and end-of-life choices" (S. Shapiro 50). Where once "newspapers used to be a lot more macho [and] there wasn"t any appetite for that kind of emotional story. It was all facts." (S. Shapiro 51 ) journalists are now penning stories, even ones primarily concerned with relaying fact and information, in ways that elicit emotional engagement with the subject and may be thought of as humanizing. Indeed, Shapiro's aforementioned statement does appear to be supported by the present study"s findings that 45 of 77 articles utilized the feature style of writing. Still, a fuller interpretation of these findings will require further research and analysis. 


\section{The Gonder Factor:}

In the coding for gender the data revealed that a higher number of men won awards compared to their female colleagues. Of the sample, 60 articles were single-authored, with men writing 42 of the articles and women 18 . As Table 11 reveals when multiple authors were involved in the authorship of an article, both women and men most frequently paired with authors of their same sex. Of all the partnership variations, a team of two males were most frequently awarded. This occurred four times more frequently than when two female authors were paired together.

Table 11: Gender Distribution of Award-winning Writers

\begin{tabular}{|l|l|l|}
\hline Single Authored & Male & 42 \\
\hline & Female & 18 \\
\hline Multi-Authored & $\mathrm{M}+\mathrm{M}$ & 8 \\
\hline \multirow{5}{*}{} & $\mathrm{F}+\mathrm{F}$ & 2 \\
\hline $\mathrm{M}+\mathrm{F}$ & 3 \\
\hline $\mathrm{M}(2)+\mathrm{F}$ & 1 \\
\hline $\mathrm{M}(3)+\mathrm{F}(2)$ & 1 \\
\hline & $\mathrm{F}(3)+\mathrm{M}(2)$ & 1 \\
\hline & $\mathrm{F}(2)+\mathrm{M}$ & 1 \\
\hline
\end{tabular}

There is merit to researching the correlation between gender and success in award-winning writing, but clearly this would be the work of another study. In this cvent, the issue of gender would be analyzed in the context of several variables such as the number of males to females in the industry, number of males versus females whose work is submitted for recognition and number of males versus females whose work is awarded. Consequently, in the absence of these ancillary data the present sludy cannot confidently determine whether or not gender plays a significant factor in the determination of award-winning writing. 


\section{LIMITATIONS}

This study aimed to develop a content-based typology of characteristics common to a sample of Canadian award-winning articles. This research focus, although important to the advancement of the study of criteria for journalistic excellence, poses some limitations that prevent this work and its lindings from being applied broadly to all newspaper articles. This is to say, although the present study was able to discover recurring themes and structures in a sample of award-winning individual journalistic pices, it is not possible to generalize from these results to award-winning arlicles outside of Canada. Similarly, it is also not possible to apply these findings with respect to excellence to the much larger corpus of non-award-winning newspaper articles.

Aside from these limitations pertaining to the applicability of the present study's findings, there is also the matter of the limitations of the research protocol. Leximancer assisted the researcher in identifying frequently recurring themes and concepts in award-winning articles, but a further validation of these concepts used as evidence of theme would occur from testing intercoder reliability by having a researcher read an article and choose a fitting theme from the same list of 30 potential themes. Although Leximancer was designed to automatically mine the data, thereby removing the potential for researcher bias, this study's research protocol could only be strengthened by the work of two teams performing different tasks with the same objective of choosing the agreed upon predominant theme in cach article in the sample. 
Given Shapiro et al's findings on the subjective nature of the judging process, the present study"s line of research using content as the basis for isolating indicators of excellence is useful. A further application of this content-based research protocol would be to study a news event with multiple interpretive possibilities and to determine which thematic emphases most frequently won awards. For example, coverage of the 2004 tsunami in south-east Asia yielded multiple articles each emphasizing a particular theme. An analysis therefore of which themes covering this event were award-winning would show which themes were more likely to win awards. This rescarch would give additional evidence of criteria for excellence discernable from awardwinning journalism, and in so doing would further validate the place of theme in journalism.

\section{CONCLUSIONS}

This study aimed to contribute preliminary evidence of the criteria that constitute excellence in award-winning Canadian journatism. Before embarking on this research, the author considered the logical expectation that theme and the structure of this theme play a significant role in inlluencing which newspaper articles are deemed excellent and consequently given award recognition. The research involved a content analysis of award-winning texts and identifying the dominant theme that characterized each story. It also entailed discerning what writing and organizational strategy the award-winning author utilized in the structure of the story. The data were further augmented with evidence of a range of other factors pertaining to the newspaper articles, including geographic focus, word count and gender of the author. 
The work of Shapiro et al., and Lamb and Moore helped give direction and focus to the present study. Like Shapiro et al. this study aimed to identify elements of excellence criteria that could be applied to individual works of journalism deemed excellent. Shapiro et al.'s study confirm that the judging process is influcnced by the subjective intuitive opinion of judges, and also by "a range of received [journalistic] values" of which writing technique ranks most highly (18).

Having identified writing as a criterion for excellence, the thematic approach taken by Lamb and Moore, provided the opportunity to investigate more deeply the subtle characteristics of writing contributing to excellence. This study identified theme as playing an important role in the selection of award-winning articles. Further, it was determined that the story's structure also contributed to award recognition, as in both the case of theme and story structure, the results favoured highly only limited possibilities.

\section{The Significance of Theme}

Findings indicate that theme does appear to be a significant and defining factor in award-winning articles, as 14 story themes were present from the list of 30 total themes proposed from earlier studies. Further, a small group of three themes common to 32 articles accounted for $42 \%$ of the total sample size.

\section{Relerance of Article Structure on Excellence}

Similarly, it would seem that not only does theme influence the potential for award recognition, but so too does the way the article is organized and presented. Of the total research corpus, more 
than half of the articles were written and presented in a feature style. That group comprised nearly twice the number of articles utilizing the hourglass style of which there were 25 , and five times more than the inverted pyramid style. It would appear that the feature style of writing which embraces techniques common to fiction and narrative journalism is becoming increasingly popular in both stories deemed "hard" and "solt" journalism and more notably, this stylistic formula is being recognized in national awards.

\section{Fartors Common to Award-Winning Articles}

This study was not only concerned with immediate features of content and presentation, but also with exogenous factors influencing the assessment of exeellence including an article"s geographic focus, the readership demographics of the host newspaper from which the awardwinning anticle originated, as well as the purely mechanical word count. Taken together, these attributes objectively found in this study"s data corpus, do indicate that a number of features common to award-winning Canadian articles can be identified. These commonalities include the dominance of large-scale newspapers in the three award competitions. Of these large, resourcerich newspapers, the Globe and Mail received the most awards and of these winning articles, the majorily focused on nationally-themed stories. When all of the winning newspapers were looked at, however, a clear local focus was noted. This emphasis on the local does correlate with the research finding that narrative is a recurring feature of award-winning journalistic writing, as the use of narrative techniques are commonly utilized to humanize a story and create a more personalized connection to the reader. 


\section{Funte Research}

Findings from this study suggest several directions for future research. First, this study determined that theme plays an important role in award-winning journalistic articles, especially when written in the journalistic leature style. As an interesting and also relevant corollary to this research finding. another study might research whether the same 14 recurring themes occur in other non-award winning newspaper articles. Discerning or failing to isolate these same themes in award-winning as well as unrecognized articles provides a way of looking at the different subtletics of theme in two different cohorts and potentially establishing successful uses of thematic emphasis. Second, although this study attempted to identify some quantifiable elements of Canadian award-winning journalism, it would be useful to test these findings against the opinion of judges tasked with recognizing journalistic excellence. Third, it is worthwhile to continue to investigate the trend towards feature style journalism as evidenced in articles with story themes rooted in traditional "hard." lact-based traditions such as business, politics and scicnce. This study would have liked to further speculate on potential reasons for the growing popularity of a feature style of journalism, but this level of depth was beyond the scope of this project. A further investigation into the prevalence of a feature style of journalism in newspapers might involve a consideration of changing readership tastes and the influence this has had on how stories are written and also awarded.

The expanding role narrative and feature style writing play in newspaper journalism today merits further analysis "particularly in a climate in which news stories double as infotainment and in which the James Frey "memoir" debacle highlighted the vanishing line between truth and 
fiction“" (S. Shapiro 52). Since the first newspaper pages were printed, the journalism industry has continually evolved and changed and in the ever-competitive and now threatened newspaper journalism industry, it is fruitful to note what stories are told and the changes in the way they are told. Industry prizes dedicated to recognizing excellence in newspaper writing affirm the importance of good journalism and challenge writers and their publications to strive to create meaningful work that impacts society. Research into what it is that constitutes this excellence in award-winning journalism not only affirms the importance of these awards, but also challenges the readership to consider the standards we hold in relation to excellence and indeed how the term is defined. There is no better way of reinforcing the importance of newspaper journalism than isolating what work stands apart from the rest and questioning what it is that makes a work excellent and why. 


\section{WORKS CITED}

Anderson, Douglas A., Bruce D. Itule. News Writing and Reporting. New York: McGraw- Hill Higher Education, 2003. 1-438.

Beasley. Berrin. "Journalists' Attitudes Toward Narrative Writing." Newspaper Research Journal $19(1998): 78-90$

Becker. L.B., R. Bcam and J. Russial. "Correlates of Daily Newspaper Performance in New England." Journalism Quarterly 55 (1978): 100-108.

Bodle, John V. "Assessing News Quality: a Comparison Between Community and Student Daily Newspapers." Journalism and Mass Communication Quarterly 73 (1996): 672-687.

Bogar1, Leo. Press and Public. New Jersey: Lawrence Erlbaum Associates, 1989. 1-359.

Bogart. Leo. "Reflections on Content Quality in Newspapers." Newspaper Research Journal 25 $(2004): 40-54$

Cloverdale. John. Raymond Nairn and Donna Claasen. "Depictions of Mental Illness in Print Media: A Prospective National Sample." Australia and New Zealand Journal of Psychiatry $36(2002): 607-700$.

Franklin, Jon. "When to Go Long." American Journalism Review 1 (1996): 36-40. 
Gardner, Howard, Mihaly Csikszentmihalyi, and William Damon. Good Work: When Excellence and Ethics Meet. New York: Basic Books, 2001.

Ghiglione, Loren. Evaluating the Press: The New England Daily Newspaper Survey Southbridge, MA: Editor, 1973.

Gladney, George A., Ivor Shapiro, and Joseph Castaldo. "Online News People's Ratings of 38 Criteria of Quality of News Web Sites." Newspaper Research Journal (2005): 1-20.

Gladney, George A. "How Editors and Readers Rank and Rate the Importance of Eighteen Traditional Standards of Newspaper Excellence." Journalism and Mass Communication Quarterly 73 (1996): 319-331.

Glasser. Theodore L., editor. The Idea of Public Journalism. New York: The Guilford Press. 1999. 3-223.

Hansen, Kathleen A. "Information Richness and Newspaper Pulitzer Prizes." Journalism Quarterly 67 (1990): 930-935.

Hansen, Anders, Simon Cottle, Ralph Negrine and Chris Newbold. Mass Communication Research Methods. New York: New York University Press, 1998.

Hart, Jack "Stories in the News," Writers Digest, September 1995, p. 29-34 
Harvey, John. "The Content Characteristics of Best-Selling Books." The Public Opinion

Quarterly $17(1953): 91-114$.

Kershner, James W. The Elements of News Writing. Boston: Pearson Education Inc., 2005. 1163.

Kovach, Bill, and Tom Rosensticl. The Elements of Journalism. New York: Crown, 2001.

Kovach, Bill; "Can Democracy Survive 2l Century Journalism?:" Amherst's Colloquium on the Constitution and the lmaging of America; Amherst, MA; October 3, 2006.

Lacy. S. F. Fico. "The Link Between Newspaper Content Quality and Circulation." Newspaper Research Journal 12 (1991): 46-57.

Hendrickson, Laura and James Tankard. "Specificily, Imagery in Writing: Testing the Effects of "Show Don"t Tell Journalism." Newspaper Rescarch Journal 73 (1996): 319 329.

McAlams Moore, Jeanie, and Chris Lamb. "Analysis Shows Trends for Pulitzer Feature Stories." Newspaper Research Journal $26(2005): 1-7$.

Merril, J., R.L. Lowenstein. Media Messages and Men: New Perspectives in Communications. New Yorl: David Mckay and Company, Ine., 1971. 
Meyer, Philip and Koang-Hyub, Kim. Quantifying Newspaper Quality: "I Know it When I See it." Delivered to the Newspaper Division Association for Education in Journalism and Mass Communications, July $30^{\text {th }}, 2003$. Kansas City, MO.

Newspaper Content: What Makes Readers More Satisfied. Media Management Center at Northwestern University, Chicago: Readership Institute, 2001.

Shapiro, Ivor, Patricia Albanese, and Leigh Doyle. Judging Journalism: What Criteria Affect the Determination of Excellence by Judges in Journalism Awards Programs? Association's Convention in San Antonio, Texas, 10 Aug. 2005, Civic Jourmalism Interest Group of the Association of Educators in Journalism and Mass Communication.

Shapiro, Stephanie. "Retum of the Sob Sisters." American Journalism Review 28 (2006): $50-58$.

Soderlund. Walter C.. R. Krause \& Price. R. "Canadian Daily New spaper Editors' Evaluation of International Reporting." Canadian Journal of Communication 16 (1991): 121-132.

Sumner, David. "A Few Tips on How to do Well in Writing Contests," Editor \& Publisher, 6 July 1996, p. 48

Stone. G.C.. D.B. Stone and E.P. Trotter. "Nowspaper Quality"s Relation to Circulation." Newspaper Rescarch Journal 2 (1981): 16-24.

Sirentz. H. "Universal Ethical Standards." Journal of Mass Media Ethics 17 (2002): 263-276. 
The New Dictionary of Cultural Literacy, 3 th ed., edited by E. D. Hirsch, Jr., et al. Boston: Houghton Mifflin, 2002

Tsalati. Yariv, Oren Meyers and Yoram Peri. "What is Good Joumalism?: Comparing Israeli Public and Joumalists Perspectives." Communication Studies 7 (2006): 152-173. 